\title{
BODY SCRUB VIRGIN COCONUT OIL, COFFEE GROUNDS AND CARBON ACTIVE COCONUT SHELL AS A MOISTURIZER AND SKIN BRIGHTENING
}

\author{
Putri Desi Eka https://orcid.org/0000-0001-6423-2693 \\ Djamil Ratna https://orcid.org/0000-0002-1863-5366 \\ Faizatun Faizatun https://orcid.org/0000-0001-5761-1118 \\ Faculty of Pharmacy, University Pancasila, South Jakarta, Indonesia \\ desiekaputri.audrii1@gmail.com
}

\begin{abstract}
Relevance. Virgin Coconut Oil (VCO) contains a lot of medium chain fatty acids, combined with coffee grounds (Coffea Arabica Linn.) and activated carbon (Activated carbon coconut Nucifera L) into a preparation that can moisturize and brighten the skin.

Objective. The purpose of this study was to make cosmetic cleansing preparations containing three natural ingredients.

Methods. This study evaluate the organoleptic body scrub preparations, homogeneity, dispensability, and $\mathrm{pH}$. The ingredients were tested using in-vivo and clinical irritation along with the effectiveness of the preparation (moisture and brightness).

Results. Organoleptic testing and homogeneity were confirmed to have dark black color, the distinctive smell of coffee, homogeneity, spreadability in the range of $4 \mathrm{~cm}$, and the $\mathrm{pH}$ was at a safe $\mathrm{pH}$ for the skin so that irritation results also did not show edema and erythema both in-vivo divided into 3 groups $(n=3)$ and clinically $(n=30)$. In addition, this body scrub provides moisture and brightness to the skin for 2 months of use, $\mathrm{p}<0.05$.
\end{abstract}

Conclusions. VCO body scrub preparations, coffee grounds and activated carbon are preparations that have the potential to be cosmetic cleansers.

Keywords: body scrub, virgin coconut oil, coffee grounds, activated carbon

Relevance. Body scrub is a body care product that can be used to maintain healthy skin. The basic ingredients for body scrubs are always the same, namely as a cleanser [1]. The basic ingredients for body scrubs are usually made from synthetics and also natural ingredients derived from herbal plants [2]. Herbal plants are one that can be used as safe pharmaceutical preparations and as cosmetics that can maintain healthy skin. One of the Indonesian herbal plants that can be used is Virgin Coconut Oil (VCO), the content of saturated fatty acids in VCO can be used as a cosmetic form because it can moisturize the skin and VCO also has a high SPF content [3]. In addition, other natural ingredients such as coffee grounds can also be used as cosmetic ingredients in skin care, because coffee has a high antioxidant content [4]. Coffee grounds also have a distinctive aroma and rough texture so they can be used to remove dead skin cells [5]. Coffee grounds also have a long life shelf for 9 months [6]. Another natural ingredient that can be used is activated charcoal which has detoxification activities [7]. The body scrubs made in this study were in the form of creams. The cream dosage has physical stability which can increase the effectiveness of active ingredients on the skin, easy to use, and easy to distribute thus consumers prefer to use cream body scrubs rather than other form of body scrub.

\section{Objective}

The purpose of this study was to make cosmetic cleansing preparations containing three natural ingredi-
Table 1

Formulation Body scrub VCO, ground coffee and activated carbon

\begin{tabular}{|l|l|l|l|}
\hline \multirow{2}{*}{\multicolumn{1}{|c|}{ Formulation }} & \multicolumn{3}{c|}{ Body Scrub Formula } \\
\cline { 2 - 4 } & \multicolumn{1}{|c|}{ F1 } & \multicolumn{1}{|c|}{ F2 } & \multicolumn{1}{c|}{ F3 } \\
\hline Virgin Coconut Oil (VCO) & 5 & 15 & 25 \\
\hline Activated Carbon & 1 & 3 & 5 \\
\hline Coffee Grounds & 9 & 7 & 5 \\
\hline $\begin{array}{l}\text { Cera de lano }{ }^{\circledR} \text { (mix of cetearyl alcohol } \\
\text { and catearat 33) }\end{array}$ & 14 & 14 & 14 \\
\hline Phenoxy Ethanol & 0.8 & 0.8 & 0.8 \\
\hline Propylene Glycol & 10 & 10 & 10 \\
\hline Liquid Paraffin & 5 & 5 & 5 \\
\hline Cetyl Alcohol & 2 & 2 & 2 \\
\hline Corn Starch & 6 & 6 & 6 \\
\hline Tween 80 & 3 & 3 & 3 \\
\hline Aquadest ad & 100 & 100 & 100 \\
\hline
\end{tabular}

ents, including virgin coconut oil, coffee grounds, and carbon active coconut shell.

\section{MATERIALS AND METHODS}

VCO and activated charcoal were obtained from Galenika (Central Java, Indonesia). Coffee grounds were obtained from several coffee shops in the Balaraja area (Tangerang, Indonesia). Cetearyl alcohol and catearate (Cera de lano) Phenoxy ethanol, propylene glycol, liquid 
paraffin, cetyl alcohol, Corn starch, Tween 80, Aquadest were obtained from Brataco (Jakarta, Indonesia).

Preparation of Body Scrub. Making body scrubs using the basic ingredient of Cera de lano, using additives phenoxy ethanol, propylene glycol, liquid paraffin, cetyl alcohol, tween.

The procedure for making a body scrub is as follows: Cera de lano is mixed over a water bath $\left(70^{\circ} \mathrm{C}\right)$ and mixed until it is homogeneous with other ingredients. For each formula (Formula I, Formula II and Formula III) add $\mathrm{VCO}$ with aquadest $\left(70^{\circ} \mathrm{C}\right)$ and mix until a white cream base is formed. Enter coffee grounds, activated charcoal and corn starch then stir using a homogenizer for about 5 minutes until a body scrub is formed.

\section{Evaluation of Body Scrub}

Organoleptic Test. Organoleptic testing is done visually with the changes in shape, color and smell of body scrub preparations. The test was carried out for 8 weeks with examination time intervals, namely at week $0,2,4,6$ and 8 at $25^{\circ} \mathrm{C}$.

Homogeneity Test. To clarify the homogeneity of body scrub preparations, homogeneity testing was carried out using a microscope (Olympus CX23) with magnification (magnification of $40 \times$ ). A number of samples are smeared on the glass preparation then the top is covered with a glass preparation. Sample testing is done by taking 3 parts of the body scrub preparation, namely top, middle, bottom [8].

Spreadability. Samples ( $0.5 \mathrm{~g})$ of each formula were placed in the centre of the Petri plate, then the Petri plate was placed on top. A load of $150 \mathrm{~g}$ is given for 1 minute at $25^{\circ} \mathrm{C}$, after which the diameter of the spread is measured. The diameter of the dispersive power should be in the range $3-5 \mathrm{~cm}$ [9].

pH Evaluation. The $\mathrm{pH}$ evaluation was carried out using a pH meter (Mettler Toledo S220). The sample is made in $1 \%$, i.e. 1 gram sample is dissolved in $100 \mathrm{~mL}$ aquadest. The acceptable $\mathrm{pH}$ is in the range 4.5-6.5 [9].

Effectiveness of Body Scrub. The humidity tester uses the Dermalab combo (Cortex) tool. Volunteers with the inclusion criteria were 17-45 years old, had healthy skin $(\mathrm{n}=30)$. While the exclusion criteria for pregnant and breastfeeding women, and / or those currently using drugs that can affect the condition of the skin. Apply the body scrub sample twice a week. Determination of skin moisture content and melanin index was carried out at 0 , 1 and 2 months after use.

Pre-Clinic and Clinical Evaluation of Body Scrub

Evaluation In-Vivo of Irritation. In vivo test for irritation (edema and erythema) used albino rabbit $(\mathrm{n}=3)$ for each treatment group. The test animals were shaved and then given body scrub samples with their respective formulas (F1, F2 and F3). The sample given is smeared with non-reactive gauze. The degree of irritation was measured from 1, 24, 48 and 72 hours. Measurements were made by giving a score of $(0)$ negative reactions;
(1) a little irritation; (2) bordered edge irritation; (3) moderate drainage $( \pm 1 \mathrm{~mm}$ rising edge; $(4)$ severe irritation (rising edge $> \pm 1 \mathrm{~mm}$ and extending beyond the curb). The score depends on the severity of the skin reactions produced [10].

Evaluation of Clinical Irritation. Clinical irritation testing was performed on the forearm with an area of $2.5 \times 2.5 \mathrm{~cm}(\mathrm{n}=30)$ for volunteers. The criteria for volunteers are 17-45 years, healthy, have no history of allergies. After the basting is done, it is left closed for 24 hours, then the observation is carried out for 72 hours to see the reaction that occurs. The irritation reaction is characterized by redness, itching and swelling. Measurements were made by giving a score of $(0)$ negative reactions; (1) redness; (2) hives; (3) swelling [11].

\section{RESULTS AND DISCUSSION}

Preparation and Evaluation Body Scrub. A body scrub has been successfully made with a cream base. Organoleptic evaluation by conducting visual observations (Figure 1a), shows that the body scrub sample containing $\mathrm{VCO}$, coffee grounds and activated carbon has a dark black color, a very sharp distinctive smell of coffee. Homogeneity testing has been carried out under a microscope (Figure 1b). The results of the observations showed that the results of each sample were homogeneous with no lumps. Homogeneity is influenced by the forming ingredients between the water base and the oil base forming a good cream mass. The dispersion test was successfully carried out for 1, 14 and 28 days (Figure 1c). The diameter of the F1, F2, and F3 spreadability tests met the requirements because they were in the $3-5 \mathrm{~cm}$ range and there was no significant difference between samples $p>0.05$. Good spreadability is obtained because the ingredients that make up cream of cetyl alcohol are fatty alcohols which form a white solid, such as wax, and catereat is an oil / water $(\mathrm{O} / \mathrm{W})$ base which can form a dense and oily mass like butter. Body scrubs have an acceptable $\mathrm{pH}$ and are a $\mathrm{pH}$ range that is safe for the skin (Figure 1d).

In tests 1,14 and 28 days, it was found that there was no significant change in $\mathrm{pH}$ in body scrub samples during the storage period $\mathrm{p}>0.05$. The $\mathrm{pH}$ is safe because catereat base material can form a stable $\mathrm{pH}$ in cosmetic preparations. In addition, the content of activated carbon has a water content of $15 \%$ which can increase the $\mathrm{pH}$ in the skin $\mathrm{pH}$ range (4.5-6.5). Evaluation of body scrub preparations obtained good results also because VCO has the stability for 48 days, where this stability affects homogeneity / appearance, changes in color, odour, consistency, $\mathrm{pH}$ and viscosity [12].

Pre-Clinic and Clinical Evaluation of Body Scrub. Clarifying the results of the in-vivo irritation test on albino rabbits $(n=3)$. The procedure carried out has been approved by the Health Research Ethics Committee, Muhammadiyah University Prof. Dr. Hamka, with ethi- 


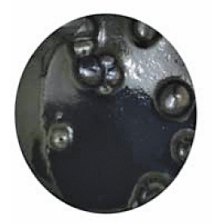

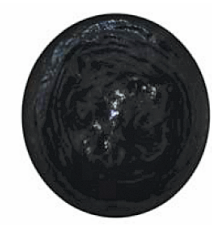

(a)

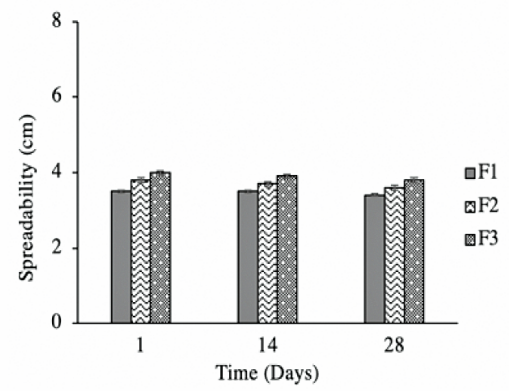

(c)
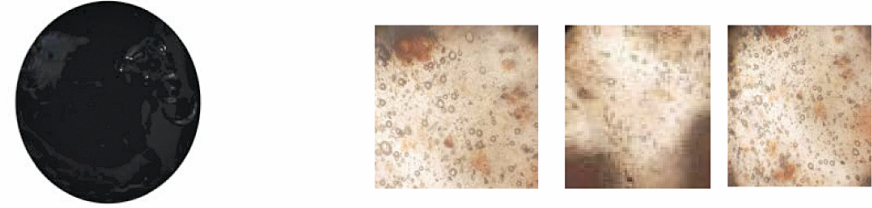

(b)

Fig. 1. Evaluation of body scrub of VCO, grounded coffee and activated carbon (F1, F2 and F3): (a) Organoleptic test; (b) Homogeneity test; (c) Spreadability test; (d) $\mathrm{pH}$

cal approval number $01 / 19.11$ / 0240. The rabbits were divided into four test groups (Figure 2a). In testing with groups F1, F2 and F3 and observations made for 1, 24, 28 and 72 hours, it was shown that body scrubs were safe to use and did not cause edema or erythema in rabbits [13].

Clinical testing of human skin, using three test groups $(n=30)$. Observation on volunteers was carried out for 72 hours (Figure 2b). The results of clinical testing using body scrubs F1, F2 and F3 confirmed negative reactions to the skin of the volunteers, meaning that no irritation occurred by testing the body scrub samples. Body scrub preparations with VCO active substances, coffee grounds and activated carbon are safe for use on human skin [14]. The absence of irritation to the skin is also influenced by the physical and chemical properties of $\mathrm{VCO}$ which is very good for use as a moisturizer on the skin. Coconut dregs which have the ability as an antioxidants are also able to absorb into the skin layer, antioxidants can neutralize free radicals [15], [16]watermelon rind extract, and combinations, also in lotion dosage form.Methods: The antioxidant activity of each extract and their combinations were tested with 2,2-diphenyl-1-picrylhydrazil method and formulated intoa lotion dosage forms. Evaluation of the lotion dosage forms, including organoleptic, homogeneity, $\mathrm{pH}$, viscosity and rheology, microbiology, acutedermal irritation test, as well as the antioxidant activity test. Results: Antioxidant activity test on the extract showed inhibitory concentration 50\% (IC50.
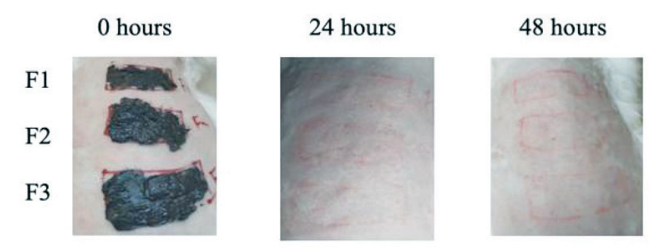

72 hours

(a)

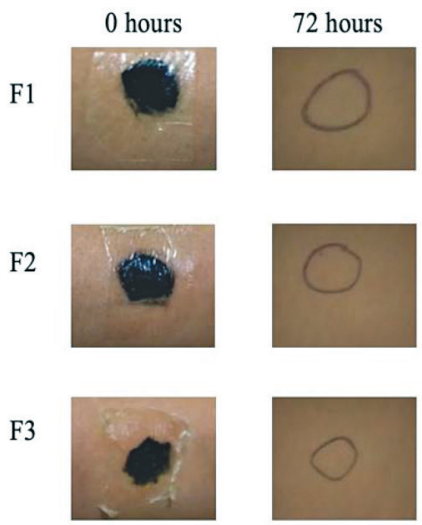

(b)

Fig. 2. Pre-Clinic and Clinical Evaluation of Body Scrub of VCO, ground coffee and activated Carbon (F1, F2 and F3): (a) Evaluation In-vivo of Irritation; (b) Evaluation of Clinical Irritation

Effectiveness of Body Scrub. The effectiveness of VCO body scrubs, coffee grounds and activated carbon by performing moisture testing (Figure $3 \mathrm{a}$ ). 


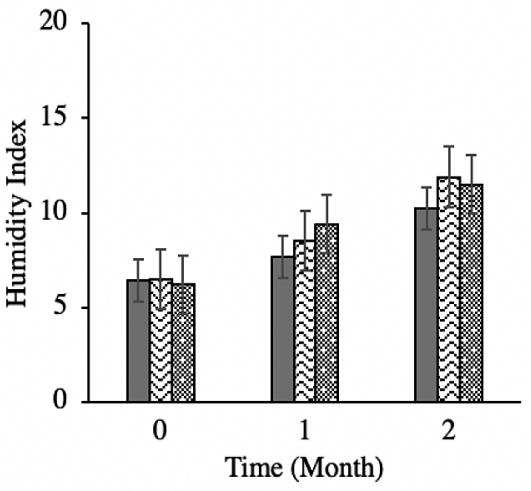

(a)

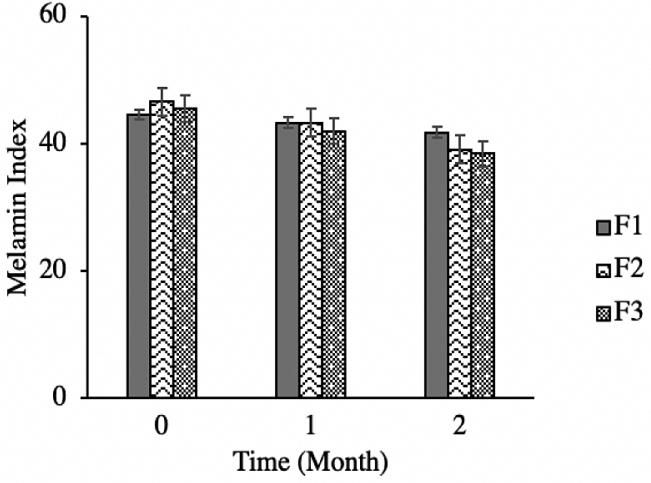

(b)

Fig. 3. Effectiveness of VCO Body Scrub, ground coffee and activated Carbon (F1, F2 and F3): (a) Humidity Index; (b) Melamine Index

Observations were made before being given treatment and after being given treatment for 0,1 and 2 months. Body scrubs used by volunteers for 2 months routinely increase moisture on the skin with a significance value of $\mathrm{p}<0.05$. While the statistical results of kruskal wallis data, there is no significant difference between formulas $p>0.05$. The results of brightness testing on VCO body scrubs, coffee grounds and activated carbon on the skin of volunteers (Figure $3 b$ ). The results showed that there was a significant difference between the time intervals of observation $p<0.05$. Comparative data between the three formulas did not have a significant difference in the increase in skin brightness in the volunteer's $p>0.05$. The effectiveness of body scrub is supported by the presence of antioxidant abilities in coffee grounds which can increase collagen productivity in the skin. The antioxidant content in skin care products, particularly vitamin C, has been shown to be beneficial in reducing melanin pigmentation in the skin.

\section{CONCLUSION}

VCO body scrub, coffee grounds and activated carbon with various formulas F1, F2 and F3 were successfully carried out with several evaluations confirmed, the difference in concentration in each formula did not affect the evaluation results of body scrubs. The $\mathrm{pH}$ of each formula is still in the safe range for the skin. The $\mathrm{pH}$ results were correlated with in-vivo and clinical irritation testing carried out for 72 hours without edema and erythema in the skin of the volunteers. The results of testing the effectiveness of moisture and brightness on VCO body scrubs, coffee grounds and activated carbon, the longer the skin is used, the more moisturized it is and the increased brightness of the volunteer skin.

\section{ACKNOWLEDGMENT}

1. Especially for my husband Muji Harja and Ananda Mufida Hazimah Amudria (Audri) who have given love, attention, encouragement, permission, bless- ings and have accompanied them during their education until completing this thesis.

2. Both parents and parents-in-law with great love and blessings so that the author can achieve this goal.

3. All parties who have helped the completion of this thesis who cannot be named individually.

4. Thank you to those who have contributed to the research and writing of this journal.

\section{REFERENCES}

1. Ulfa M., Khairi N., Maryam F. Formulasi dan Evaluasi Fisik Krim Body Scrub dari Ekstrak Teh Hitam (Camellia sinensis), Variasi Konsentrasi Emulgator Span-Tween 60. J. Farm. 2016; 4(4): 179-185. DOI: $10.24252 / . v 4 i 4.2257$

View at: Publisher Site: http://journal.uin-alauddin. ac.id/index.php/jurnal_farmasi/article/view/2257

URL: http://journal.uin-alauddin.ac.id/index.php/ jurnal_farmasi/article/viewFile/2257/2192

2. Ervina A., Santoso J., Prasetyo B.F., Setyaningsih I., Tarman K. Formulation and characterization of body scrub using marine alga Halimeda macroloba, chitosan and konjac flour. IOP Conf. Ser. Earth Environ. Sci. 2020; 414:012004. DOI: 10.1088/1755-1315/414/1/012004 View at: Publisher Site: https://iopscience.iop.org/ article/10.1088/1755-1315/414/1/012004

3. Mu'awanah I.A.U., Setiaji B., Syoufian A. Pengaruh Konsentrasi Virgin Coconut Oil (VCO) Terhadap Stabilitas Emulsi Kosmetik dan Nilai Sun Protection Factor (SPF). J. Math. Nat. Sci. 2014; 24(1):1-10.

View at: Publisher Site: https://jurnal.ugm.ac.id/bimipa/ article/view/13840

URL: https://media.neliti.com/media/publications/242420-pengaruh-konsentrasi-virgin-coconut-oil-49a0486e.pdf:

4. Hertina T.N. Dwiyanti S. Pemanfaatan Ampas Kedelai Putih dan Ampas Kopi dengan Perbandingan Berbeda dalam Pembuatan Lulur Traditional untuk Perawatan Tubuh. J. Tata Rias. 2013; 2(3): 70-77.

View at: Publisher Site: https://jurnalmahasiswa.unesa. ac.id/index.php/jurnal-tata-rias/article/view/4064 
URL: https://jurnalmahasiswa.unesa.ac.id/index.php/ jurnal-tata-rias/article/view/4064/2027

5. Desyntia D. Sehat Dengan Secangkir Kopi. Surabaya, 2012.

6. Ningsi S., Nonci F.Y.N., Sam R. Formulasi Sediaan Lulur Krim Ampas Kedelai Putih dan Ampas Kopi Arabika. J. Farm. 2015; 3(1):1-4. DOI: 10.24252/.v3i1.2173 View at: Publisher Site: http://journal.uin-alauddin. ac.id/index.php/jurnal_farmasi/article/view/2173 URL: http://journal.uin-alauddin.ac.id/index.php/ jurnal_farmasi/article/download/2173/2097

7. Lestari U., Farid F., Sari P.M. Formulasi dan Uji Sifat Fisik Lulur Body Scrub Arang Aktif Dari Cangkang Sawit ( Elaeis Guineensis Jacg) Sebagai Detoksifikasi. J. Sains dan Teknol. Farm. 2017; 19(1).

View at: Publisher Site: https://garuda.ristekbrin.go.id/ documents/detail/621600

8. Zhang J.-T., Huang S.-W., Zhuo R.-X. Preparation and Characterization of Novel Temperature Sensitive Poly(N-isopropylacrylamide-co-acryloyl beta-cyclodextrin) Hydrogels with Fast Shrinking Kinetics. Macromol. Chem. Phys. 2004 Jan; 205(1): 107-13. DOI: 10.1002/macp. 200350080

View at: Publisher Site: https://onlinelibrary.wiley.com/ doi/abs/10.1002/macp.200350080

URL: http://www.paper.edu.cn/scholar/showpdf/ MUT2ANzIMTD0gx1h

9. Fitriani L., Afifah, Ismed F., Bakhtiar A. Hydrogel Formulation of Usnic Acid and Antibacterial Activity Test Against Propionibacterium acne. Sci. Pharm. 2018 Dec; 87(1): 1. DOI: $10.3390 /$ scipharm 87010001

View at: Publisher Site: https://www.mdpi. com/2218-0532/87/1/1

URL: https://pdfs.semanticscholar.org/c864/ b9370025071d6927ada2dacf3906215e79dd.pdf

10. Peraturan Kepala Badan Pengawasan Obat dan Makanan tentang Pedoman Uji Toksisitas Non Klinik Secara In Vivo. Jakarta, 2014. 18 p.

View at: URL: https://jdih.pom.go.id/download/ product/701/13/2014

11. Tranggono R.I. Ilmu Pengetahuan Kosmetik, Djajadisas. PT Gramedia Pusat Utama, 2007.

12. Padmadisastra Y., Widodo S., Syaugi A. Pembuatan Basis Krim VCO (Virgin Coconut Oil) Menggunakan Microwave Oven. IOCD International Symposium and Seminar of Indonesian Medicinal Plants XXXI, Surabaya 9-11 April 2007. 2007. p.1-11

View at: URL: http://pustaka.unpad.ac.id/wp-content/ uploads/2009/06/efektivitas_emulgator_vco.pdf https://docplayer.info/54766253-Pembuatan-basis-krim-vco-virgin-coconut-oil-menggunakan-microwave-oven.html

13. Widiarti S.I.M. Formulasi Dan Uji Sifat Fisik Lulur Serbuk Kulit Buah Manggis (Garcinia Mangostana Linn) Dan Serbuk Kopi (Coffea Arabica Linn) Untuk Perawatan Tubuh Formulation. J. Kesehat. Al-Irsyad. 2017; X(1).

View at: Publisher Site: https://jka.stikesalirsyadclp. ac.id/index.php/jka/article/view/67

14. Hui S.B.L., Susilohadi G. Structure analysis of health-related indicators of the elderly at home with a focus on subjective health. Procedia - Soc. Behav. Sci. 2014; 2(1)

15. Alamsyah N., Djamil R., Rahmat D. Antioxidant activity of combination banana peel (musa paradisiaca) and watermelon rind (citrullus vulgaris) extract in lotion dosage form. Asian J. Pharm. Clin. Res. 2016 Dec; 9(9): 300. DOI: 10.22159/ajpcr.2016.v9s3.14926

View at: Publisher Site: https://innovareacademics.in/ journals/index.php/ajpcr/article/view/14926

16. Djamil R., Wahyudi P., Wahono S.M.H. Antioxidant Activity Flavonoid from Anredera Cordifolia (TEN) Steenis Leaves. Int. Res. J. Pharm. 2012; 3(9).

$$
\begin{array}{r}
\text { Article history } \\
\text { Received: } 01.03 .2021 \\
\text { Revision requested: } 10.03 .2021 \\
\text { Revision received: } 20.03 .2021 \\
\text { Accepted: } 29.03 .2021 \\
\text { Published: } 31.03 .2021
\end{array}
$$

\title{
СКРАБ ДЛЯ ТІЛА 3 КОКОСОВИМ МАСЛОМ ПЕРШОГО ВІДЖИМУ, КАВОВОЮ ГУЩЕЮ І АКТИВОВАНИМ ВУГІЛЛЯМ ІЗ ШКАРАЛУПИ КОКОСА ЯК ЗВОЛОЖУВАЧ І ОСВІТЛЮВАЧ ШКІРИ
}

\author{
Путрі Д.С., Джсаміл Р., Файзатун Ф. \\ Фармацевтичний факультет, Університет Панкасіла, Південна Джакарта, Індонезія \\ desiekaputri.audrii1@gmail.com
}

\begin{abstract}
Актуальність. На сьогоднішній день залишається невивченою можливість застосовувати для зволоження і освітлення шкіри препарат, що містить кокосове масло першого віджиму (VCO), з великим вмістом середньоланцюгових жирних кислот, в поєднанні $з$ кавовою гущею (Coffea Arabica Linn.) і активованим вугіллям (кокосове активоване вугілля Nucifera L ).

Мета: приготувати косметичні очищаючі препарати, що містять три натуральних інгредієнти.

Методи. У цьому дослідженні оцінювали органолептичні склади скрабів для тіла, однорідність, що дозується, і рН. Інгредієнти були протестовані in vivo. Оцінювали ефективність препарату (вологість і яскравість).

Результати. Органолептичні випробування і гомогенність підтвердили наявність темно-чорного кольору, характерного запаху кави, однорідності, розтікання в діапазоні 4 см. pН був безпечним для шкіри, застосування скрабу в клінічних випробуваннях $(\mathrm{n}=30)$ не викликало ні набряку, ні еритеми. Крім того, цей скраб для тіла забезпечує зволоження і чистоту шкіри протягом 2 місяців використання, $\mathrm{p}<0,05$.
\end{abstract}


Висновок. Скраб для тіла, що містить VCO, кавову гущу і активоване вугілля - це препарат, який може бути косметичним засобом, що очищає.

Ключові слова: скраб для тіла, кокосове масло першого віджиму, кавова гуща, активоване вугілля.

\title{
СКРАБ ДЛЯ ТЕЛА С КОКОСОВЫМ МАСЛОМ ПЕРВОГО ОТЖИМА, КОФЕЙНОЙ ГУЩЕЙ И АКТИВИРОВАННЫМ УГЛЕМ ИЗ СКОРЛУПЫ КОКОСА КАК УВЛАЖНИТЕЛЬ И ОТБЕЛИВАТЕЛЬ КОЖИ
}

\author{
Путри Д.Е., Джамил Р., Файзатун Ф.
}

Фармацеевтический факультет, Университет Панкасила, Южная Джакарта, Индонезия

desiekaputri.audrii1@gmail.com

Актуальность. На сегодняшний день остаётся неизученной возможность применять для увлажнения и осветления кожи препарат, содержащий кокосовое масло первого отжима (VCO), с большим содержанием среднецепочечных жирных кислот, в сочетании с кофейной гущей (Coffea Arabica Linn.) и активированным углем (кокосовый активированный уголь Nucifera L).

Цель: приготовить косметические очищающие препараты, содержащие три натуральных ингредиента.

Методы. В этом исследовании оценивали органолептические составы скрабов для тела, однородность, дозируемость и рН. Ингредиенты были протестированы in vivo. Оценивали эффективность препарата (влажность и яркость).

Результаты. Органолептические испытания и гомогенность подтвердили наличие темно-черного цвета, характерного запаха кофе, однородности, растекаемости в диапазоне 4 см. pH был безопасным для кожи, применение скраба в клинических испытаних $(\mathrm{n}=30)$ не вызывало ни отёка, ни эритемы. Кроме того, этот скраб для тела обеспечивает увлажнение и чистоту кожи в течение 2 месяцев использования, $\mathrm{p}<0,05$.

Вывод. Скраб для тела, содержащий VCO, кофейную гущу и активированный уголь - это препарат, который может быть косметическим очищающим средством.

Ключевые слова: скраб для тела, кокосовое масло первого отжима, кофейная гуща, активированный уголь. 